\title{
Mirror Image Pinna: A Rare Case Report
}

\author{
${ }^{1}$ Purnima Joshi, ${ }^{2}$ Rajiv Jain, ${ }^{3}$ Priyanko Chakraborty, ${ }^{4}$ Sidharth Pradhan, ${ }^{5}$ Rakhi Kumari
}

\section{ABSTRACT}

Aim: To report a rare congenital anomaly of the external ear.

Background: Pinna or the external ear is the branchial apparatus derivative which may be anomalous due to error in embryological development many such anomalies are reported as anotia, microtia, preauricular sinus or cysts, tags, bat ear, etc. double pinna or the mirror image pinna is one such anomaly as others it may or may not be associated with syndromes.

Case description: A 9-year-old boy presented with left ear mirror image pinna and right ear preauricular tag had no other complaints. On systemic examination, no abnormality was detected. The patient was advised surgery which was deferred by the patient for time being.

Conclusion: Mirror image pinna is a rare congenital malformation which may or may not be associated with any syndromes. Surgical correction is possible which is done usually at age of $5-6$ years.

Clinical significance: To know the rare congenital malformation, its probable embryological cause, associated features, and its correction.

Keywords: Hillocks, Mirror image pinna, Polyotia, Tubercles.

How to cite this article: Joshi $P$, Jain $R$, Chakraborty $P$, Pradhan S, Kumari R. Mirror Image Pinna: A Rare Case Report. Int J Otorhinolaryngol Clin 2017;9(3):106-108.

Source of support: Nil

Conflict of interest: None

\section{INTRODUCTION}

Pinna or the external ear is the branchial apparatus derivative errors in embryological development of the same may result in several anomalies such as anotia, microtia, preauricular sinus or cysts, tags, bat ear, etc. Double pinna or the mirror image pinna is one such anomaly. Congenital anomalies of the ear are one in every 3800 births. ${ }^{1}$ The incidence of outer ear malformations has been reported at 1:6000 newborns ${ }^{2}$ to 1:6830 newborns. ${ }^{3}$ These constitute macrotia, abnormal folds, preauricular

\footnotetext{
1,3-5 Junior Resident, ${ }^{2} \mathrm{Head}$

${ }^{1-5}$ Department of Otorhinolaryngology, Institute of Medical Sciences, Banaras Hindu University, Varanasi, Uttar Pradesh, India

Corresponding Author: Purnima Joshi, Junior Resident, Department of Otorhinolaryngology, Institute of Medical Sciences, Banaras Hindu University, Varanasi, Uttar Pradesh, India, e-mail: purnimajoshi4@gmail.com
}

tags, preauricular sinus, and microtia with or without associated meatal atresia. These may be associated with systemic anomalies together comprising of a syndrome. Hearing loss is found associated with microtia or another outer ear anomaly. It is not always necessary to treat these but may be done for cosmetic reasons. We herewith put forth a case of mirror image pinna, presenting to us in our outpatient department (OPD).

\section{CASE SUMMARY}

A 9-year-old boy, presented to the OPD with the congenitally malformed ear. There were no associated complaints of hearing loss, ear discharge, tinnitus, or any other systemic complaint.

On examination of the left ear (Fig. 1), there was a mirror pinna present, along with the normally located pinna. The mirror image pinna was smaller, and its upper border was present at the level of crus, had helix, antihelix, and concha. No tragus was present. The normally located pinna had all parts with normal dimensions and slope. External auditory meatus appeared normal.

Right ear (Fig. 2) had a preauricular tag, which was located just in front of the tragus. Normally located ear, was more laterally placed, had lopping present, with incomplete antihelix superiorly. Rest of pinna looked normal with the normal external auditory canal.

On otoscopic examination, B/L tympanic membranes appeared normal, with no specific findings in anterior rhinoscopy. Tuning fork tests and pure tone audiometry was normal (Graph 1). On oral examination, oral cavity, palate, and oropharynx were found normal.

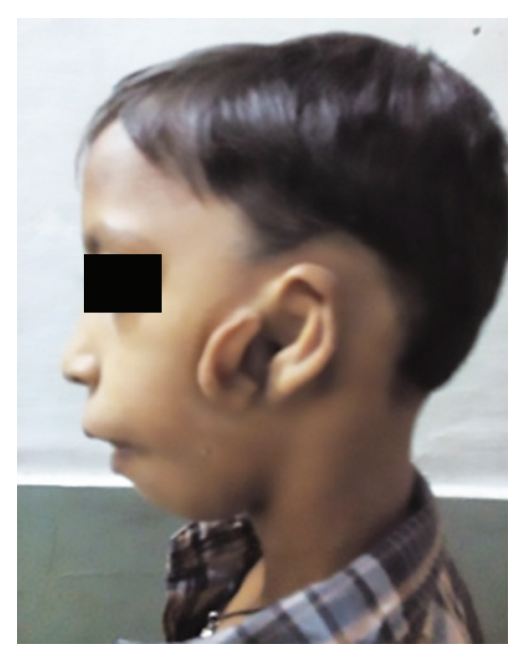

Fig. 1: Left mirror image pinna 


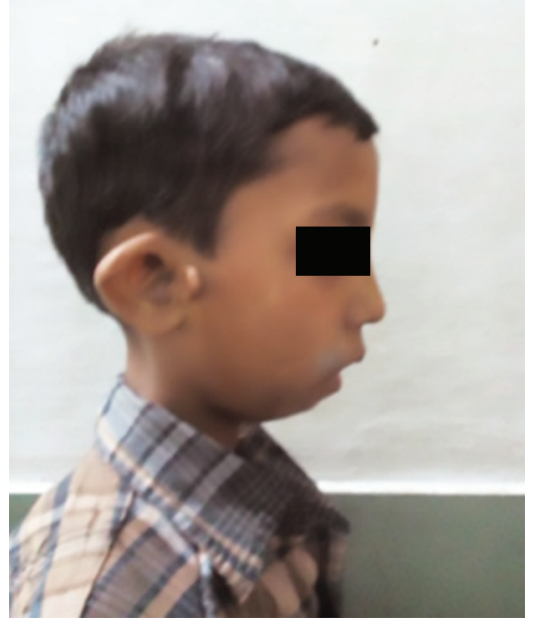

Fig. 2: Right ear showing preauricular tag

The patient had telecanthus and micrognathia (Fig. 3) and no other features suggestive of any syndromic association. His psychosocial development appeared normal, with normal developmental milestones. Mother had no history of drug intake as isotretinoin in pregnancy. There was no family history of such anomaly in the family.

The patient was advised genetic testing (cri-du-chat syndrome or Treacher Collins syndrome) and surgery, but he was lost to follow-up.

\section{DISCUSSION}

Pinna or the external ear is embryologically derived from the six hillocks. These hillocks derive in the mesenchymal tissue of the first two branchial arches, i.e. first the mandibular and second the hyoid. First, second, and third hillocks are derived from the first branchial arch and form the anterior portion of the ear lobule, tragus and root of the helix respectively. While the fourth, fifth form the antihelix and the helix, the sixth hillock forms the posterior lobule. Concha originates from the second branchial cleft. Incomplete fusions of the hillocks form the clefts, while the hypergenesis causes the tags, polyotia or the mirror image pinna, ${ }^{5}$ migration of neural crest cells in branchial arch during embryological development, ${ }^{6}$ outgrowths of mandibular tissue on the margins of first branchial groove., ${ }^{7,8}$

Polyotia is found associated with many syndromes as Treacher Collins syndrome, cri-du-chat syndrome, Goldenhar syndrome, ${ }^{9}$ Wildervanck syndrome, cartilages cell rests in the neck, ${ }^{5}$ or as an isolated anomaly. ${ }^{10}$

Isotretinoin intake is also found associated with polyotia. ${ }^{6}$

Surgical repair mainly comprises of releasing the skin of the cartilage, trimming the cartilage and unwanted skin, burying the cartilage to the conchal hollow, resuturing the skin. ${ }^{5}$ An alternative technique involves releasing the skin of cartilage, collapsing the conchal hollow using the quilting sutures, and reconstructing the new tragus using

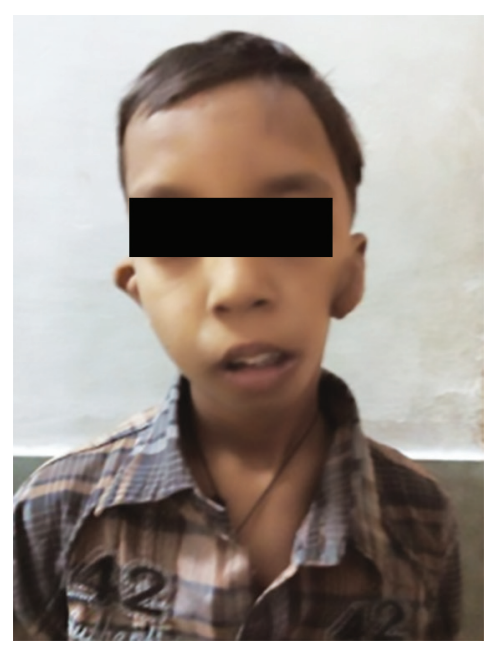

Fig. 3: Telecanthus and micrognathia

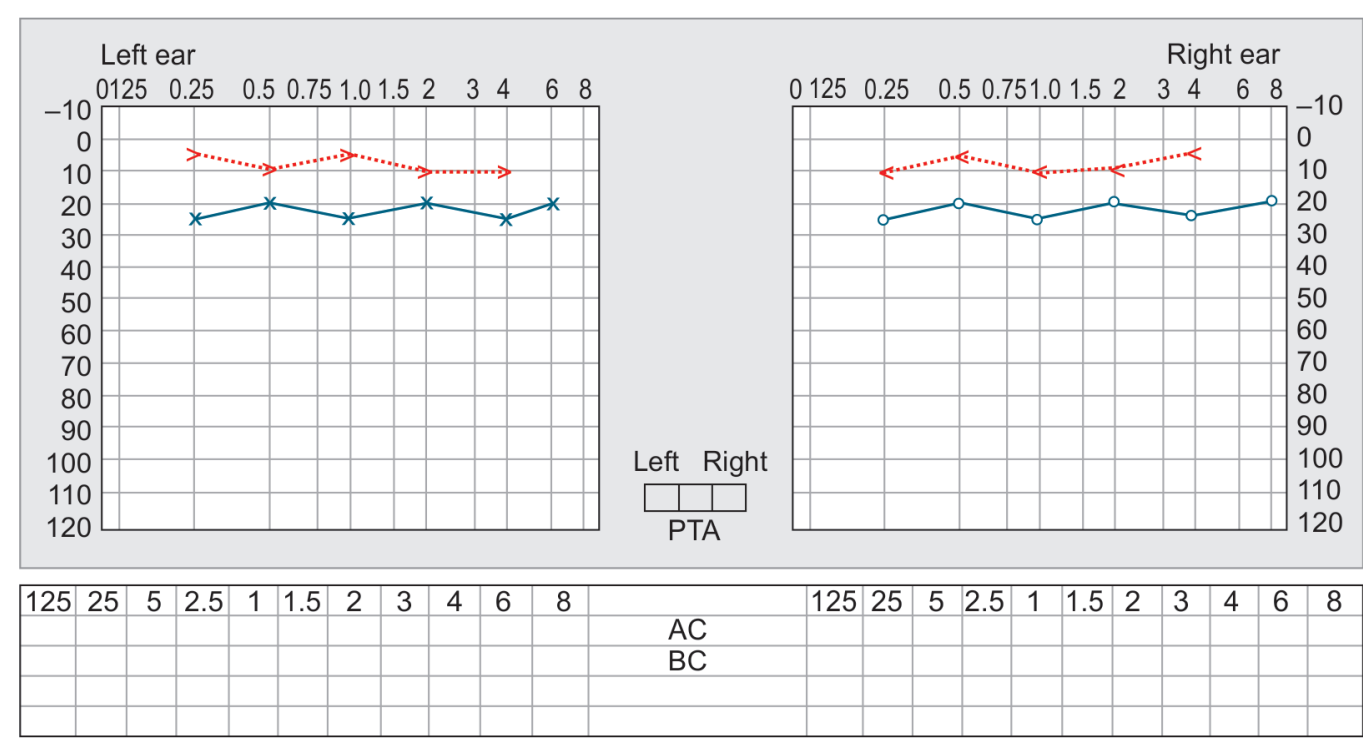

Graph 1: Pure tone audiogram of the patient 
the chondro-cutaneous composite flap from the marginal portion of the excessive structure, as opposed to just trimming or following the previously mentioned technique, which excised all of the accessory components. ${ }^{11}$

\section{CONCLUSION}

Mirror image pinna is a rare congenital external ear anomaly, which may be part of a syndrome or may be associated with middle or inner ear defects. It can be easily corrected surgically and thus has a good cosmetic outcome.

\section{REFERENCES}

1. Thorn L. Entwicklung des Ohres (einschließlichEntstehung von Missbildungen, experimentelleEmbryologie und In-vitro-Studien).In: Helms J, Hrsg. Oto-Rhino-Laryngologie in Klinik und Praxis. Bd. 1. Stuttgart: Thieme; 1994. S. 1-22.

2. Brent B. The pediatrician's role in caring for patients withcongenital microtia and atresia. Pediatr Ann 1999;28:374.
3. Conway H, Wagner K. Congenital anomalies of the head andneck. Plast Reconstr Surg 1965;36:71-79.

4. Katzbach R, Klaiber S, Nitsch S, et al. Ohrmuschelre konstruktion beihochgradiger Mikrotie. HNO 2006;54:493-514.

5. Gault D, Rothera M. Management of congenital deformities of the external and middle ear, Scott Brown's otorhinolaryngology, head and neck surgery 7th edition. p. 965-986.

6. Lammer E. Preliminary observations on isotretinoin-induced ear malformations and pattern formation of the external ear. J Craniofac Genet Dev Biol 1991;11:292-295.

7. Otto HD. Pathogenese der Aurikularanhänge, Melotieund Polyotie Arch Otorhinolaryngol 1979;225(1):45-56.

8. Otto HD. Pathogenese der branchiogenenÜberschussbildungen.HNO Praxis. 1983;8:161-169:247-257.

9. Gore SM, Myers SR, Gault D. Mirror ear: a reconstructive technique for substantial tragal anomalies or polyotia. J Plast Reconstr Aesthet Surg 2006;59:499-504.

10. Bajaj Y, Sahni JK, Jain A, Kansal Y. Polyotia. Arch Otolaryngol Head Neck Surg 2001;127:75-77.

11. Moon IY, Oh KS. Surgical Correction of an Accessory Auricle, Polyotia, Archives of Plastic Surgery 2014;41:427-429. 